\title{
Associations Between the Big Five Personality Traits and a Medical School Admission Interview
}

\author{
Associação Entre os Traços de Personalidade e uma \\ Entrevista de Admissão a uma Escola Médica
}

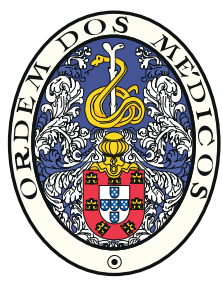

Isabel LOURINHO $\rrbracket^{1}$, André MOREIRA ${ }^{2}$, Rui MOTA-CARDOSO ${ }^{3}$, Milton SEVERO ${ }^{1,4}$, Maria Amélia FERREIRA ${ }^{1}$

Acta Med Port 2016 Dec;29(12):796-802 - http://dx.doi.org/10.20344/amp.8390

ABSTRACT

Introduction: Personality has became popular in medical student's selection. However, few research exists about the association between the big five personality traits and the existent medical school selection tools. Our aim was to study which personality traits were selected by a medical school admission interview.

Material and Methods: One hundred ninety four graduate applicants that had applied to the Faculty of Medicine of the University of Porto through the graduate entry approach, after ranked on previous achievement, were interviewed between the academic years of 2011 and 2013. From these, 181 (93.3\%) answered to the NEO Five-Factor Inventory that assesses high order personality traits of openness to experience, conscientiousness, extraversion, agreeableness and neuroticism. Admission interview corresponded to the second phase of the seriation process. Every applicant was interviewed and scored by three interviewers on seven dimensions asesssed by Lickert scale (1-10). Interview score was the sum of the dimensions. Linear mixed effects model and respective regression coefficients were used to estimate the association between personality traits from each interviewer's score. Final models were adjusted for gender, interviewers and previous achievement.

Results: Openness to experience (Beta $=0.18$ : $\mathrm{Cl} 95 \%: 0.05 ; 0.30$ ) had the strongest association with interview score followed by the interaction effect between the extraversion and conscientiousness traits (Beta $=0.14 ; \mathrm{Cl} 95 \%$ : 0.02; 0.25). Also, applicants scored higher when their gender was opposite to the interviewers.

Discussion: Previous achievement and interview score had no association.

Conclusion: Our admission interview selected different personality traits when compared to other selection tools. Medical schools should be aware of the implications of the adopted selection tools on the admitted medical student's personality because it can help providing beneficial interventions.

Keywords: Interviews as Topic; Personality; Portugal; School Admission Criteria; Schools, Medical; Students, Medical/psychology.

\section{RESUMO}

Introdução: A avaliaçao da personalidade tem ganho popularidade na seleção de estudantes de medicina. Todavia, existe pouca investigação acerca dos traços de personalidade escolhidos pelos diferentes métodos de seleção. O nosso objetivo consistiu em estudar os traços de personalidade selecionados através de uma entrevista de admissão a uma escola médica.

Material e Métodos: Cento e noventa e quatro candidatos licenciados concorreram à Faculdade de Medicina da Universidade do Porto pelo contingente especial e foram entrevistados nos anos académicos de 2011-2013. Cento e oitenta e um (93,3\%) responderam ao NEO Five-Factor Inventory que avalia os traços de abertura à experiência, conscienciosidade, extraversão, agradabilidade e neuroticismo. A entrevista correspondia à segunda fase do processo de seriação. Cada candidato foi entrevistado e avaliado por três entrevistadores relativamente a sete dimensões por escala de Lickert (1-10). O resultado da entrevista correspondia à soma das classificações das dimensões. Utilizaram-se modelos de efeitos lineares mistos e respetivos coeficientes de regressão para estimar a associação entre os traços de personalidade com o score dos entrevistadores. Os modelos finais foram ajustados para género, entrevistadores e sucesso prévio.

Resultados: Abertura à experiência (Beta $=0,18$ : IC 95\%: 0,05; 0,30) apresentou a associação mais forte com o score da entrevista seguida da interação entre os traços de extraversão e consciensciosidade (Beta $=0,14$; IC 95\%: 0,02; 0,25). Os candidadatos tinham maior score quando o seu género era oposto ao dos entrevistadores.

Discussão: Não houve associação entre o sucesso prévio e o score da entrevista.

Conclusão: A entrevista de admissão escolheu traços de personalidade diferentes dos escolhidos por outros métodos de seleção. As escolas médicas poderão planear intervenções adequadas se conhecerem as implicações dos processos de seleção na personalidade dos estudantes admitidos.

Palavras-chave: Critérios de Admissão Escolar; Entrevista; Escolas Médicas; Estudantes de Medicina; Personalidade; Portugal.

\section{INTRODUCTION}

The selection of medical students is the first step to ensure the development of tomorrow's physicians. ${ }^{1}$ For many years this selection was exclusively weighed on academic achievement. Changes brought the use of

interviews in the selection of medical students, ${ }^{2}$ and in the last decade, the multiple mini-interview (MMI) has also become a popular selection tool..$^{2,3}$

Moreover, there are other medical selection tools such

1. Department of Medical Education and Simulation. Faculty of Medicine. University of Porto. Porto. Portugal.

2. Immunology Department. Faculty of Medicine. University of Porto. Porto. Portugal.

3. Department of Clinical Neurosciences and Mental Health. Faculty of Medicine. University of Porto. Porto. Portugal.

4. EPIUnit - Institute of Public Health. University of Porto. Porto. Portugal.

$\bowtie$ Autor correspondente: Isabel Lourinho. i.lourinho@med.up.pt

Recebido: 31 de outubro de 2016 - Aceite: 30 de novembro de 2016 | Copyright @ Ordem dos Médicos 2016 
as references, personal statements, letters of intent, essays and/or situational judgement tests ${ }^{2}$ - some of which aim to select other non-academic characteristics. The assessment of personal attributes has had more followers in recent years $^{4-6}$ and the inclusion of personality and emotional intelligence (as selection tools) has been under much debate. ${ }^{7,8}$ Nowadays, personality assessment has been at the forefront ${ }^{8,9}$ of medical selection criteria and the same is true of other career areas such as business or commerce. ${ }^{8}$ It is currently possible to assess personality with intruments such as the NEO Personality Inventory (NEO PI-r), which is increasingly used in medical education. ${ }^{6-8}$ This instrument is available for the assessment of the five-factor model (FFM) that comprises the broad trait dimensions of openness to experience, conscientiousness, extraversion, agreeableness, neuroticism and their more specific facets as one of the most widely accepted taxonomic structures of personality. ${ }^{10}$ This model provides a framework of informed personality research in organisational studies ${ }^{11}$ due to its ability to predict the performance of individuals in different occupational settings ${ }^{12}$ mostly because of the conscientiousness trait suggested as being the most consistent trait in predicting good work outcomes across different contexts. ${ }^{11}$ A review of personality and medical education has also emphasised the conscientiousness trait as a significant long term success predictor in medical training. ${ }^{13}$

Personality can be assessed directly by self-report personality tests but it has been shown that applicants can fake on personality self-report tests. ${ }^{14}$ Or we can study which are the personality traits that are selected by the existing selection tools. In the medical education field, the existing studies about who is being selected for medical schools have relied mostly on written tests or academic achievements and more recently on MMI. In these studies, results show the positive effect of the 'conscientiousness' and of the 'extraversion' traits ${ }^{15,16}$ in the selection score, but it is still unknown which traits are selected during other interview methods in the selection of medical students.

At the Faculty of Medicine of the University of Porto (FMUP), the graduate entry approach comprised for some years, a two-phase selection process: previous achievement and an admission interview. The first phase of the seriation process ranked applicants based on their previous achievement once it has been showed that previous achievement predicts posterior achievement. ${ }^{2,17,18}$ Neverthless, it isn't absolutely certain that high achievers have other important attributes that are needed from the very beginning. ${ }^{2}$ In this context, FMUP's selection committee decided to hold an admission interview in order to pursue other personal characteristics of the admitted applicants. And from among the available selection tools, only two require the existence of external examiners: interviews and MMI. We opted by the admission interview because 1) it is one of the most common medical selection measures highly valued by admission committees ${ }^{2,19}$ and by interviewers ${ }^{2} ; 2$ ) there was no validation of either of the two tools at the time; 3) FMUP had institutional policies of cost containment and $\mathrm{MMI}$ could lead to higher costs. ${ }^{20}$ Furthermore, it is important to mention that there have been several attempts to increase the reliability and validity of interviews ${ }^{21}$ by establishing a more structured format ${ }^{22,23}$ and by providing interviewers with specific training, ${ }^{24}$ which was taken into account in our admission interview design and implementation. Therefore, this study aimed to assess which personality traits were selected by a medical school admission interview.

\section{MATERIAL AND METHODS \\ Context}

Since the academic year of 2007/2008, Portuguese medical schools, besides secondary school-leaver entrants, also started to have a graduate entry mode. Every Portuguese medical school has its own criteria for the admission of graduates, and at FMUP secondary school leavers have 245 places avalailable per year and the graduate entry approach has 37 places. In addition, FMUP's graduate admission scheme, at the time of this stidy was a two-phase selection process that comprised previous achievement and an admission interview.

\section{Seriation process of the graduate entry mode at FMUP}

Phase one (P1) was associated with previous achievement and applicants were ranked in descending order compared to their average grades obtained in national examinations at the end of secondary education in the subjects of Mathematics, Chemistry and Biology.

The 74 applicants with the highest averages become eligible for phase two (P2) - the admission interview ( $\mathrm{N}=$ 74 corresponds to twice the number of places available for this entry mode). If the main goal of the first phase was to sort among the highest achievers, the admission interview aimed to select other personal characteristics that go beyond academic success.

In the years of 2011, 2012 and 2013, 309 graduate applicants applied to FMUP, a total of 194 were interviewed and 94 were admitted as medical students.

\section{Personality traits}

Personality traits were assessed through the short version of the NEO Personality Inventory (NEO-PI-R), which is called NEO Five-Factor Inventory (NEO-FFI). This 60-item, multiple-choice questionnaire evaluates the five main dimensions of personality: openness to experience, conscientiousness, extraversion, agreeableness and neuroticism in a five-point Likert scale that ranges from 0 (strongly disagree) to 4 (strongly agree). Additionally, the NEO-FFI has already been validated on the Portuguese population. ${ }^{25}$

This assessment ocurred during the application period to FMUP (April 2011, April 2012 and April 2013) and every applicant was asked to participate in the study. They were informed that their collaboration would not have any consequences on the selection process and 
that the selection committee would not have acess to their information. Therefore, participants voluntarily completed this personality measure (as part of a larger psychometric battery). Questionnaires were sent to the applicants by e-mail and they had two weeks to answer the questions in their own time (unsupervised).

\section{Admission interview}

Admission interview $(\mathrm{Al})$ refers to the second phase of the seriation process, which entailed the adoption of, between the years of 2011 and 2013, a fixed panel interview format made up of three interviewers.

Interviewer 1 was a male and was aged 38 during the first year of interviewing. Interviewer 2 was a 30 yearold female and Interviewer 3 was a 57 year-old female. Interviewer 2 was a clinical psychologist and interviewers 1 and 3 were medical doctors and held a position in basic sciences at FMUP. All of the interviewers had selection experience in both postgraduate admissions and at other Portuguese medical schools.

The interview script and the methodologies to be used were developed by the interviewers in colaboration with a Human Resources consulting company. Consequently, an "Interviewer's Manual" was produced and interviewers were trained before participating.

The interview had seven general dimensions: 'Motivations to study medicine', 'Scientific and medical culture', 'Academic or professional routes and other developed activities', 'Humanistic culture', 'Career transition', 'Time and stress management' and 'Overall performance in the interview'. Every dimension was given a score by the three interviewers with the use of a Likert scale (1 to 10 range). Accordingly, interviewers had to score every applicant on each dimension with the following scale: (1-2) totally inappropriate, (3-4) inappropriate, (5-6) sufficient, (7$8)$ above average and (9-10) outstanding.

Naturally, every dimension was previously clearly defined, which included characteristics and job competencies that would be needed for someone to be proficient as a medical student and as a physician. A pool of questions was designed for every dimension and interviewers participated equally in the interview process by asking three questions per dimension.

To ensure greater evaluation objectiveness and transparency, assessment guidelines were made available for the interviewers. These guidelines had general rating indicators such as: level of preparation for the interview, critical thinking, communication skills and emotional control. Further to these competencies that should be demonstrated in all of the answers, there were other specific rating indicators. Hence, for example, regarding the 'Scientific and medical culture' dimension, applicants who had shown to know Portugal's strategic plan for health and were able to freely dicuss it would have a better score. The assessment occurred throughout the interview process or imediatelly after it, was done individually and interviewers were not allowed to exchange any infomation about the applicant's performance. Likewise, interviewers had no access to application forms and interviews lasted between thirty to forty minutes. Additionally, interviewers had to answer an extra question that did not contribute to the interview's score: 'Should this applicant be admitted to FMUP?' - a research question designed to study the internal validity of the Al.

\section{Participants}

This study considered the applicants that were interviewed and that had completed the NEO-FFI during their application to FMUP. There was a total of 181 participants which represented $93.29 \%$ of the total population interviewed $(n=194)$.

Furthermore, this study was reviewed and had the approval of the Ethics Committee of the Faculty of Medicine of the University of Porto/S. João Hospital Centre (public corporation); participants provided their written informed consent to participate in this study and were fully aware that this collaboration would not have any consequences on the selection process or beyond (in case of admittance to FMUP).

\section{Data analysis}

To study the reliability of the $\mathrm{Al}$, the variance components of applicants, dimensions and interviewers were estimated and the absolute reliability of the Al was calculated.

The variance components were estimated using a random effect model with random effect by applicant, dimension and interviewers as well as all of the possible two-way interaction effects.

Conjointly, in order to reach a reliability of 0.7 , the optimum number of interviewers and dimensions were studied.

The score of each interviewer was calculated as being the sum of the seven dimensions.

What is more, a linear mixed effects model with a random effect by applicant to estimate the association between personality traits and each interviewer's score was used. The Beta coefficients from the mixed effects model were used to estimate the association between the score of the interviewer and the five personality traits.

All of the quantitative variables in the model (applicants' score, personality traits and the 'should be admitted' question) were standardised.

Final models were adjusted for gender, interviewer and for previous achivement. Other applicants' personal characteristics, such as age, ethnicity, marital status, parents' qualifications or the application year were also studied, but did not influence the final score of the interview (data not shown).

The quantitative variables like personality traits and previous achievement were standardised in order to compare the effect between variables. 
Table 1 - Components of variance of the admission interview

\begin{tabular}{lcccc}
\hline & $\mathrm{n}$ & Variance & SD & \% total variance \\
\hline Applicants & 194 & 0.847 & 0.920 & 30.0 \\
Dimensions & 7 & 0.299 & 0.547 & 10.6 \\
Interviewers & 3 & 0.024 & 0.154 & 0.8 \\
Applicants x Dimensions & 1321 & 0.165 & 0.406 & 5.8 \\
Applicants X Interviewers & 565 & 0.576 & 0.758 & 20.4 \\
Dimensions x Interviewers & 15 & 0.122 & 0.349 & 4.3 \\
Residual (D X I X A)* & 4072 & 0.794 & 0.891 & 28.1 \\
\hline
\end{tabular}

${ }^{*} \mathrm{~A}$ : Applicants; I: Interviewers; D: Dimensions

\section{RESULTS}

\section{Characterisation of the participants}

From the 181 participants, 39 were men $(21.5 \%)$ and 142 were women $(78.5 \%)$; the majority were single $(80.7 \%)$ and the mean age was $27.28( \pm 3.46)$. The participants were all white and with the exception of a Brazilian applicant, everyone else (99.4\%) was Portuguese.

In terms of the education level of the participants' parents, the interquartile range varied from incomplete secondary education to PhD holders. Most of the respondents' parents were employed, $60.0 \%$ (mother) and $59.4 \%$ (father), respectively.

\section{Reliability of admission interview}

Table 1 shows that the main source of variance in the $\mathrm{Al}$ were the applicants $(30.0 \%)$, and it demonstrates that most of the variability in the assessment was due to differences between applicants. This was as expected considering that the purpose of the interviews was to differentiate applicants. The second main source of variance (20.4\%) was the interaction 'Applicants $x$ Interviewers' that shows that some applicants do better or worse with specific interviewers. The remaining components together explain $21.5 \%$ of the variability of the final score interview. Finally, the residual percentage $(28.1 \%)$ was considerable in comparison to

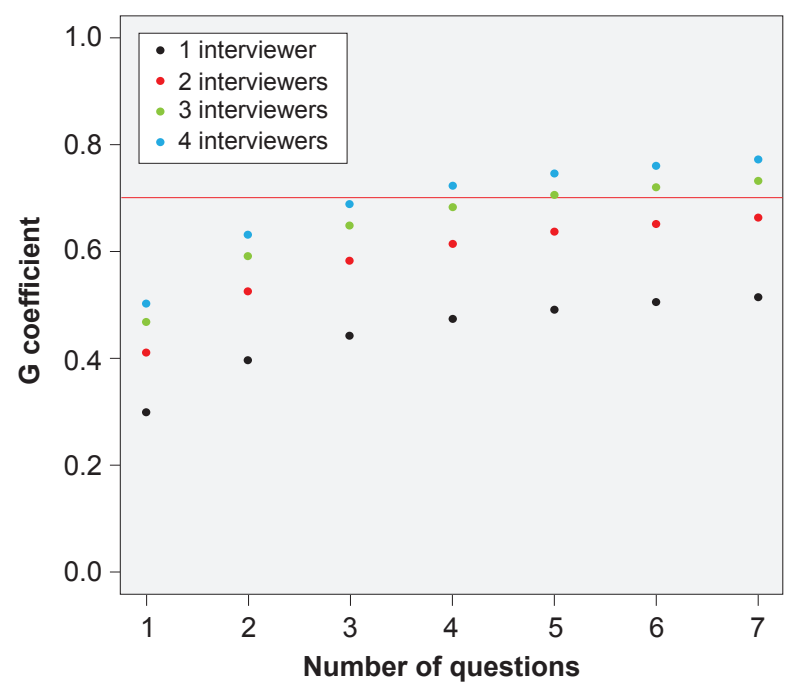

Figure 1 - Reliability coefficient according to the number of questions and number of interviewers the remaining sources of variance, which means that other sources of variance exist and are worthy of identification.

The absolute reliability of this interview with seven dimensions and executed by three interviewers was 0.73 .

However, it was also possible to estimate that the cutpoint of 0.7 of reliability of this interview could be achieved by keeping the same number of interviewers and reducing the number of dimensions to a maximum of five (Fig. 1).

\section{Personality traits and admission interview}

The openness to experience trait was positively associated with the final score of the $\mathrm{Al}$ (Beta $=0.18$ : $\mathrm{Cl}$ 95\%: 0.05; 0.30) (Table 2, Model 1). Moreover, a positive interaction between extraversion and conscientiousness traits and the final score of the Al was also obvious (Beta = 0.14; Cl 95\%: 0.02; 0.25) (Table 2, Model 1).

Concerning the other personality traits, no significant associations with the final score of the Al was demonstrated (Table 2, Model 1).

Gender differences were visible in the interview's scoring. This is, when the gender of the applicants was opposite to that of the interviewers, applicants had higher scores (gender of applicants: interviewers) (Table 2, Model 1).

After adjusting the research question 'Should this applicant be admitted to FMUP?', the same personality traits remain significant. Notwithstanding, the effect of openness to experience and the extraversion and conscientiousness interaction effect decreased approximately 50\%. This research question showed a strong association with the final score of the $\mathrm{Al}$ (Beta $=0.61 ; \mathrm{Cl} 95 \%$ : 0.55; 0.68).

Previous achievement did not show a significant association with the final score of the $\mathrm{Al}$ (Table 2, Model 1).

\section{DISCUSSION}

There was no association between the final score of the $\mathrm{Al}$ and previous achievement, showing that our $\mathrm{Al}$ measures different personal attributes when compared with a selection tool exclusively based on achievement. This was the expectation once our admission interview explicitly aimed selecting other personal characteristics. Regarding what personality traits were selected by the AI, results show a strong association with the open-ness to experience trait, followed by the interaction effect between the extraversion and conscientiousness traits. Openess to experience is 
Table 2 - Mixed effects models with random effect by applicant for the standardised score of the interviewers

\begin{tabular}{|c|c|c|}
\hline & Model 1 & Model 2 \\
\hline Applicants' Gender & $\beta(\mathrm{Cl} 95 \%)$ & $\beta(\mathrm{Cl} 95 \%)$ \\
\hline Female & Ref & Ref \\
\hline Male & $-0.20(-0.55 ; 0.16)$ & $-0.10(-0.22 ; 0.02)$ \\
\hline \multicolumn{3}{|l|}{ Interviewers } \\
\hline 1 & Ref & Ref \\
\hline 2 & $0.22(0.07 ; 0.37)$ & $-0.24(-0.49 ; 0.02)$ \\
\hline 3 & $0.15(0.00 ; 0.30)$ & $0.07(-0.08 ; 0.22)$ \\
\hline \multicolumn{3}{|l|}{ Applicants's Gender: Interviewers } \\
\hline Male Applicants: Interviewer 1 & Ref & \\
\hline Male Applicants: Interviewer 2 & $0.34(0.02 ; 0.66)$ & $0.32(0.01 ; 0.63)$ \\
\hline Male Applicants: Interviewer 3 & $0.65(0.33 ; 0.97)$ & $0.44(0.12 ; 0.75)$ \\
\hline \multicolumn{3}{|l|}{ Academic Achievements } \\
\hline Biology & $-0.02(-0.16 ; 0.12)$ & $-0.05(-0.14 ; 0.03)$ \\
\hline Mathematics & $-0.04(-0.16 ; 0.09)$ & $-0.03(-0.10 ; 0.04)$ \\
\hline Chemistry & $-0.03(-0.18 ; 0.11)$ & $-0.02(-0.11 ; 0.06)$ \\
\hline \multicolumn{3}{|l|}{ Personality Traits } \\
\hline Neuroticism ${ }^{1}$ & $-0.02(-0.16 ; 0.12)$ & $0.01(-0.07 ; 0.09)$ \\
\hline Extraversion $^{1}$ & $0.07(-0.07 ; 021)$ & $0.03(-0.05 ; 0.12)$ \\
\hline Openness to experience ${ }^{1}$ & $0.18(0.05 ; 0.30)$ & $0.08(0.01 ; 0.16)$ \\
\hline Agreebleness $^{1}$ & $-0.04(-0.19 ; 0.10)$ & $0.02(-0.07 ; 0.10)$ \\
\hline Conscientiousness $^{1}$ & $-0.12(-0.26 ; 0.02)$ & $-0.10(-0.18 ;-0.01)$ \\
\hline Extraversion: Conscientiousness ${ }^{1}$ & $0.14(0.02 ; 0.25)$ & $0.09(0.02 ; 0.15)$ \\
\hline 'Should this applicant be admitted to FMUP?' & --- & $0.61(0.55 ; 0.68)$ \\
\hline
\end{tabular}

Model 1: Adjusted for all the variables in the table with the exception of 'Should this applicant be admitted to FMUP?'

Model 2: Adjusted for all the variables in the table;

${ }^{1}$ The variables were standardised

linked with creativity and divergent thinking, ${ }^{26}$ with being imaginative ${ }^{27}$ flexible, inclined towards new ideas ${ }^{28}$ and with being more empathetic, ${ }^{29,30}$ which can be advantageous in academic and/or work performance metrics (clerkship evaluations, patient care) of future physicians. This result is different when compared with studies on MMI where extraversion is the trait that has the major effect. It is possible that high scores in the openness to experience trait and high scores in the $\mathrm{Al}$ are due to the assessment guidelines that valued either critical thinking either original and spontaneous answers. Thus, these competencies can be easily expressed for those who tend to adopt different perspective-taking, i.e. high in openness to experience. ${ }^{31}$

Results also show an interaction between interview scores and the extraversion and conscientiousness traits. Once again, these are different results when compared with $\mathrm{MMI}^{15,16}$ because during the Al applicants had to be, simultaneously, high-extravert and high-conscientious. If high extraverts tend to be sociable and energetic, ${ }^{32}$ they can also lose status over time. ${ }^{33}$ High scorers on conscientiousness are individuals that reveal to be responsible and industrious s,32 $^{9,3}$ seem more likely to outperform others, ${ }^{11}$ but being overly conscientious may compromise fast decision-making. ${ }^{34}$ This result can be a consequence of the amount of time that applicants had to spend with the three different interviewers at the same time, which can increase pressure but also provide interviewers a holistic understanding of the applicants. Subsequently, if on the one hand the most extravert applicants are impressive at the beginning due to their communication skills, as time passes, and when question complexity increases, they must clearly evidence knowledge. On the other hand, having the required knowledge is not enough if they are not able to express themselves clearly. Thence, the Al can be seen as an advantage when compared with other selection tools in which eight minutes is the maximum amount of time that examiners and interviewees can spend together. ${ }^{35}$ This is so because it is easier to 'keep the mask on' when there is less interaction time. Inclusively, lengthening station duration has already been recommended for MMI. ${ }^{36,37}$

In any case, it is important to mention that these characteristics were observed in a group of participants that had already been pre-selected based on their previous achievement.

Although the focus of this study was on the personality of the applicants, it is not possible to ignore the fact that the personality of the interviewers can also affect the final score had in the interviews. This happened, for example, with 
gender. Results show that gender influences the final score of the Al. We found that when the gender of the applicants was different from that of the interviewers' they had a higher interview score. In some studies women applicants were scored lower than men by both male and female interviewers, ${ }^{38}$ and in other studies female applicants were scored higher than male applicants during the interview process. ${ }^{39}$ This finding has an important implication as it addresses the need to have more studies on the impact of gender on selection, but mainly on how to build assessment committees and improve methodologies that involve external examiners such as interviews and MMI.

A possible limitation of this study could be the reliability and validity of the Al. Still, the Al on which this study was based showed similar reliability with previous MMI studies. In actual fact, whilst overall reliability in interviews for the selection of medical students tends to be poor, ${ }^{4,21,24}$ this study showed a good reliability $(0.73)$ in consonance with other results. ${ }^{23}$ Furthermore, a good reliability of the MMI was established with a median reliability of $0.73^{36}$ and a recent systematic review about the MMI for student selection in health professions still in training reported a moderate to high reliability, with Cronbach's alpha $=0.69$ an G-coefficient $=0.55-0.72 .{ }^{40}$ Moreover, this finding can be associated with the colaboration of a Human Resources consulting company that ensured that the design and implementation of the interviews was executed with attention to accuracy and detail. They oversaw, for example, the prior and clear understanding of the definition of the selection criteria for each dimension, the questions to be asked, the interview structure, the previous training of the interviewers and the assessment guidelines. In truth, this is not very different from the recommendations that were recently addressed to MMI, 3,37,41 which highlight the importance of a careful and rigourous design. Equally, it is imperative to meet the need to align the vision and mission of medical schools with the students who are selected. In addition, this study shows that maintaining the same number of interviewers $(n=3)$ and reducing the dimensions to be assessed to a maximum of five items, the mentioned Al would have identical reliability. Convincingly, results show the internal validity of the Al as its

\section{REFERENCES}

1. Mahon KE, Henderson MK, Kirch DG. Selecting tomorrow's physicians: the key to the future health care workforce. Acad Med. 2013;88:1806-11.

2. Patterson F, Knight A, Dowell J, Nicholson S, Cousans F, Cleland J. How effective are selection methods in medical education? A systematic review. Med Educ. 2016;50:36-60.

3. Rees EL, Hawarden AW, Dent G, Hays R, Bates J, Hassell AB. Evidence regarding the utility of multiple mini-interview (MMI) for selection to undergraduate health programs: A BEME systematic review: BEME Guide No. 37. Med Teach. 2016:1-13.

4. Albanese MA, Snow MH, Skochelak SE, Huggett KN, Farrell PM. Assessing personal qualities in medical school admissions. Acad Med. 2003;78:313-21.

5. Mahon KE, Henderson MK, Kirch DG. Selecting tomorrow's physicians: the key to the future health care workforce. Acad Med. 2013;88:18061811.

6. Patterson F, Zibarras L, Ashworth V. Situational judgement tests in medical education and training: Research, theory and practice: AMEE final score was strongly related with the research question that interviewers had to answer.

This study's major limitation is the fact that it was conducted at only one medical school which could make it unclear as to whether these findings could be generalised to other settings. However, at least $12 \%$ of the applicants are common to other three Portuguese medical schools that have different selection criteria for the graduate entry mode, whereby there is confidence that, at the very least, these findings can be extrapolated to Portugal.

\section{CONCLUSION}

In conclusion, this study shows that the executed $\mathrm{Al}$ is reliable and selects different personal traits when compared to other selection tools. If the selection of medical students is the first step to ensure the development of tomorrow's physicians, ${ }^{1}$ medical schools should be aware of the implications of the adopted selection tools on the admitted medical student's personality. Also, we believe that the information gathered during the selection process can provide beneficial interventions. ${ }^{42}$ Future research should focus on worthwhile correlations with selection tools and should provide clear, solid and practical clinical outcomes.

\section{PROTECTION OF HUMANS AND ANIMALS \& DATA CONFIDENTIALITY}

This study was reviewed and had the approval of the Ethics Committee of the Faculty of Medicine of the University of Porto/S. João Hospital Centre (public corporation); participants provided their written informed consent to participate in this study and were fully aware that this collaboration would not have any consequences on the selection process or beyond (in case of admittance to FMUP).

\section{CONFLICTS OF INTEREST}

The authors declare that there are no conflicts of interest.

\section{FUNDING SOURCES}

No subsidies or grants contributed to this work.
Guide No. 100. Med Teach. 2015:1-15

7. Hojat M, Erdmann JB, Gonnella JS. Personality assessments and outcomes in medical education and the practice of medicine: AMEE Guide No. 79. Med Teach. 2013;35:e1267-301.

8. Prideaux D, Roberts C, Eva K, Centeno A, McCrorie P, McManus C, et al. Assessment for selection for the health care professions and specialty training: consensus statement and recommendations from the Ottawa 2010 Conference. Med Teach. 2011;33:215-23.

9. Ferguson E, James D, Madeley L. Factors associated with success in medical school: systematic review of the literature. BMJ. 2002;324:9527.

10. Costa PT, McCrae RR. The revised neo personality inventory (neo-pi-r). In: Boyle GJ, Matthews G, Saklofske DH, editors. The SAGE handbook of personality theory and assessment. London: SAGE Publications; 2008. p. 179-98

11. Barrick MR, Mount MK, Judge TA. Personality and performance at the beginning of the new millennium: What do we know and where do we go 
next? Int J Select Assess. 2001;9:9-30.

12. Thoresen CJ, Bradley JC, Bliese PD, Thoresen JD. The big five personality traits and individual job performance growth trajectories in maintenance and transitional job stages. J Appl Psychol. 2004;89:83553.

13. Doherty EM, Nugent E. Personality factors and medical training: a review of the literature. Med Educ. 2011;45:132-40.

14. Lourinho I, Ferreira MA, Severo M. Self-report personality tests and medical school selection. Psicol. Refl. Crít. 2016;29:48.

15. Griffin B, Wilson I. Associations between the big five personality factors and multiple mini-interviews. Adv Health Sci Educ Theory Pract. 2012;17:377-88.

16. Jerant A, Griffin E, Rainwater J, Henderson M, Sousa F, Bertakis KD, Fenton JJ, Franks P. Does applicant personality influence multiple miniinterview performance and medical school acceptance offers? Acad Med. 2012;87:1250-9.

17. Doherty EM, Nugent E. Personality factors and medical training: a review of the literature. Med Educ. 2011;45:132-40.

18. Hojat M, Erdmann JB, Gonnella JS. Personality assessments and outcomes in medical education and the practice of medicine: AMEE Guide No. 79. Med Teach. 2013;35:e1267-301.

19. Kulatunga Moruzi C, Norman GR. Validity of admissions measures in predicting performance outcomes: the contribution of cognitive and noncognitive dimensions. Teach Learn Med. 2002;14:34-42.

20. Rosenfeld JM, Reiter HI, Trinh K, Eva KW. A cost efficiency comparison between the multiple mini-interview and traditional admissions interviews. Adv Health Sci Educ Theory Pract. 2008;13:43-58.

21. Kreiter $C D$, Yin $P$, Solow $C$, Brennan RL. Investigating the reliability of the medical school admissions interview. Adv Health Sci Educ Theory Pract. 2004;9:147-59.

22. Patrick LE, Altmaier EM, Kuperman S, Ugolini K. A structured interview for medical school admission, Phase 1: initial procedures and results. Acad Med. 2001;76:66-71.

23. Poole A, Catano VM, Cunningham DP. Predicting performance in Canadian dental schools: the new CDA structured interview, a new personality assessment, and the DAT. J Dent Educ. 2007;71:664-76.

24. Salvatori P. Reliability and Validity of Admissions Tools Used to Select Students for the Health Professions. Adv Health Sci Educ. 2001;6:15975.

25. James D, Ferguson E, Powis D, Symonds I, Yates J. Graduate entry to medicine: widening academic and socio-demographic access. Med Educ. 2008;42:294-300.

26. McCrae RR. Creativity, divergent thinking, and openness to experience. J Pers Soc Psychol. 1987;52:1258.

27. Laher S. Structural equivalence and the NEO-PI-R: implications for the applicability of the five-factor model of personality in an African context: theoretical research. J Ind Psychol. 2008;34:76-80.

28. John OP, Srivastava S. The Big Five trait taxonomy: History, measurement, and theoretical perspectives. Handb Pers Theory Res. 1999;2:102-38.

29. Lourinho I, Severo M. Are personality traits really weak/moderate predictors of empathy? Med Teach. 2013;35:611.

30. Magalhaes E, Costa P, Costa MJ. Empathy of medical students and personality: evidence from the Five-Factor Model. Med Teach. 2012;34:807-12.

31. Carver CS, Connor-Smith J. Personality and coping. Annu Rev Psychol. 2010;61:679-704.

32. Ferguson E. Personality is of central concern to understand health: towards a theoretical model for health psychology. Health Psychol Rev. 2013;7(Suppl 1):S32-70.

33. Bendersky $\mathrm{C}$, Shah $\mathrm{N}$. The downfall of extraverts and rise of neurotics: The dynamic process of status allocation in task groups. Acad Manag J. 2012:amj. 2011.0316.

34. Tett R. Is conscientiousness always positively related to job performance. The Industrial-Organizational Psychologist. 1998;36:24-9.

35. Eva KW, Rosenfeld J, Reiter HI, Norman GR. An admissions OSCE: the multiple mini-interview. Med Educ. 2004;38:314-26.

36. Eva KW, Reiter HI, Trinh K, Wasi P, Rosenfeld J, Norman GR. Predictive validity of the multiple mini-interview for selecting medical trainees. Med Educ. 2009;43:767-75.

37. Kelly ME, Dowell J, Husbands A, Newell J, O'Flynn S, Kropmans T, Dunne FP, Murphy AW. The fairness, predictive validity and acceptability of multiple mini interview in an internationally diverse student population-a mixed methods study. BMC Med Educ. 2014;14:267.

38. Arvey RD. Unfair discrimination in the employment interview: Legal and psychological aspects. Psychol Bull. 1979;86:736

39. Shaw DL, Martz DM, Lancaster CJ, Sade RM. Influence of medical schoo applicants' demographic and cognitive characteristics on interviewers' ratings of noncognitive traits. Academic Medicine. 1995;70:532-36.

40. Pau A, Jeevaratnam K, Chen YS, Fall AA, Khoo C, Nadarajah VD. The Multiple Mini-Interview (MMI) for student selection in health professions training - a systematic review. Med Teach. 2013;35:1027-41.

41. Roberts C, Walton M, Rothnie I, Crossley J, Lyon P, Kumar K, Tiller D. Factors affecting the utility of the multiple mini-interview in selecting candidates for graduate-entry medical school. Med Educ. 2008;42:396404.

42. Lourinho I, Loureiro E, Ferreira MA, Severo M. Self-concept and obsessive-compulsiveness as moderators of anxiety and depression: a Portuguese prospective study. Porto Biomed J. 2016;1:36-9. 